Review

\title{
Towards the Systemization of Energy Policy Studies
}

\author{
Kazutomo IRIE \\ (Received October 6, 2008) \\ エネルギー政策学の体系化に向けて \\ 入江 一友
}

In order to make consistent policy recommendations on interrelated various energy issues, the systematization of energy policy studies will be required. In this review, first the current situations of publication and education of energy policy studies are surveyed for reference. No book with the title of "energy policy studies" has ever been published in Japan. Quite a few Japanese universities offer courses on energy policy studies at undergraduate or graduate level. Then those of environmental policy studies, which is one of the neighboring areas to energy policy studies, are surveyed. As for environmental policy studies, introductory books have already been published in Japanese and many Japanese universities offer undergraduate and graduate level courses. Referring to the systematization of environmental policy studies in publication and education, energy policy studies can be systematized as the combination of four approaches: a) historical approach, b) policy area approach, c) policy tool approach, and d) research technique approach.

\section{Key Words}

Systematization, Energy policy studies, Environmental policy studies

\section{1. 研究の背景・目的}

エネルギーは経済社会活動の基礎をなすものであり， その供給と需要の両面において生じる経済的·社会的·技 術的・環境的その他種々の諸問題に対して, 政府は様々 な手法によって関与介入している。こうした政府の関与 介入を総称して“エネルギー政策”と呼ぶことができる。

エネルギー政策上の諸課題については，様々な観点か ら研究が行われ, 個々の課題に関する研究成果も公表さ れてきている。学問領域としては, 経済学・政治学といっ た社会科学からの研究もあれば, 法律学による研究もあ り，特にエネルギーにおける技術的要素の重要性から工 学における研究が活発に行われている。また, その中に は，現実のエネルギー政策がどのように形成され，機能 しているかについての“分析 (analysis)”に関わる研究 と，エネルギー政策がいかにあるべきかの“処方 (prescription)”に関わる研究の双方が含まれる。

しかし，エネルギー政策上の諸課題は相互に関連して おり，包括的に俯瞰し，全体として整合性のある提言を 行うためには，エネルギー政策に関する関連諸科学の研

Graduate School of Engineering, The University of Tokyo 2-11-16, Yayoi, Bunkyo-ku, Tokyo 113-0032, Japan
究成果を“エネルギー政策学”として体系化することが 必要と考えられる脚注1)。

このような観点から, エネルギー政策学に関する出版 及び教育の現状を観察し, さらに隣接学問領域での体系 化を参照して, エネルギー政策学体系の試案を演繹的に 示してみることとした。

\section{2. 出版及び教育の現状}

\section{1 出版の現状}

国立国会図書館は，法令の規定によりわが国で刊行さ れた全ての書籍が納本されることとなっているが，その 蔵書検索サイトで調べたところ，“エネルギー政策学”な いし“エネルギー政策論”を表題に含む書籍を見出すこ とができない。同サイトでは，表題のみならず内容細目 （分担執筆の場合の各文章の表題）も検索できるが, “工 ネルギー政策学”ないし “エネルギー政策論”を内容細 目に含む書籍も見出すことができない。

“エネルギー政策”を表題ないし内容細目に含む書籍を 検索すると, 和図書 185 件が挙げられるが, 表題と著者

東京大学大学院工学系研究科原子力国際専攻

于 113-0032 東京都文京区弥生 2-11-16 
を見る限り，日本を含む各国のエネルギー政策を紹介す るもの，エネルギー政策に関する審議会答申，エネルギー 政策上の個々の課題 (たとえば水素エネルギーの開発)を 論じたものばかりで，体系的な教科書と思われるものは 見当たらなかった脚注2)。

ちなみに国立国会図書館では，和図書ほど網羅的では ないにせよ，かなりの数の洋図書も所蔵しているので，海 外におけるエネルギー政策教科書の存否も探索してみる こととした。“energy”, “policy”及び“studies”の 3 単 語を表題・内容細目に含む洋図書は 56 件を数えるが，表 題を見る限り，体系的教科書である可能性が高いものは Energy policy (edited by J. S. Aronofsky, A. G. Rao, M. S. Shakun)のみであった。

また, “energy”, “policy”及び “study”の 3 単語で検 索しなおすと，該当洋図書は26件となり，文字通り Energy Policy Studyと題する書籍が挙げられているが，米国エネ ルギー省エネルギー情報局が出版したものであり，副題 に Effects of oil regulation on prices and quantities と付さ れているので，米国政府の施策解説書であって教科書で はないものと思われる。

なお，“energy”及び“policy”の 2 単語を表題・内容 細目に含む洋図書を検索すると758件に及んだ。“energy policy”と連続した単語では検索できないため，正確な対 比は難しいが, “エネルギー政策”を表題ないし内容細目 に含む和図書の 185 件に比べ 4 倍以上の件数となる。諸 外国（おそらく米国）におけるエネルギー政策研究の活 発さを推測させるものであり，わが国においても更なる 研究の必要性を示唆するものと思われる。

\section{2 教育の現状}

京都大学には大学院エネルギー科学研究科の中にエネ ルギー政策学研究室（正確には，エネルギー社会・環境 科学専攻 エネルギー社会論講座 エネルギー政策学分野) が置かれており，神田啓治・中込良廣両教授の退任後は
宇根崎博信教授が教育研究の任に当たっている。修士 1 年を対象とする科目として“エネルギー政策論”が開講 されており，同科目のシラバスによれば，“エネルギー需 給の中長期的な展望をふまえ，エネルギー政策について， エネルギー資源，エネルギー源の各論，環境問題とのか かわり, 主要国の情勢, 将来展望について述べる”とさ れている。

同様にエネルギー政策学の研究室又は専任教員の所在 を各大学のホームページから調べてみたところ， 2 例の み見出すことができた。

まず，京都女子大学現代社会学部の蒲生孝治教授が工 ネルギー政策学を専門分野の一つに挙げている。同大学 大学院現代社会研究科公共圈創成専攻の開講科目一覧に おいては，修士課程及び博士前期課程に“エネルギー政 策研究”，博士後期課程に “エネルギー政策特殊研究”が 掲げられており，いずれも蒲生教授が担当している。

上記の修士課程及び博士前期課程の科目のシラバスに よれば，授業概要（目標）は“まずエネルギー利用に関 わる基本的な事項，用語と考え方，エネルギー技術，お よびエネルギーの生成・転換・消費，効率化による環境 および社会への影響といった基礎知識を理解する。次い で，社会的な価值観，経済性，そして持続可能な社会に 向けたエネルギー政策上の課題を検討し，解決するため の方策を考える”とされている。教科書としては，電力 中央研究所エネルギー教育研究会編著の『講座 現代エ ネルギー・環境論 [改定新版]』4)が採用されている。

上記の博士後期課程の科目のシラバスによれば，授業 概要（目標）は“2005 年 4 月に策定された『京都議定書 目標達成計画』及びその後の追加政策をベースに，21世 紀日本の地球温暖化対策に関するエネルギー政策を研究 する”とされており，教科書としては政府の地球温暖化 対策推進本部事務局他監修の『京都議定書目標達成計画 の全容』5) が使用されている。

また，立命館大学政策科学部の周緯生教授がエネル
脚注 1）エネルギー政策学に限らず，“政策学”あるいは“政策 科学”一般について, 独立した学問領域として成立し うるか，成立しうるとしてどのように定義するか，さ らに, 関連諸科学との関係をどのように理解すべきか, については議論が続けられてきた（例えば，宮川公男 『政策科学の基礎』1)。エネルギー政策学の場合には, エ ネルギー問題に扮ける工学的側面の重要性から, 関連 諸科学の一つであるシステム工学に扮けるエネルギー システム分析との関係が特に問題になりうる。ここで はさしあたり，エネルギー政策学ではエネルギーシス テムの中でも政府の行動に焦点が当たることを指摘す るとともに，足立幸男が『政策学的思考とは何か』2) の 中で政策学と工学の違いについて述べている所論に従 い，エネルギー政策学では，政策目的の妥当性や政策 手段の優劣の判定基準に関する，価値判断を伴った研 究が重要となりうることを指摘しておきたい。
脚注 2) エネルギー問題を体系的に論じようとする書籍におい て，エネルギー政策にも言及する結果，エネルギー政 策についてもある程度体系的に論じることとなる場合 も考えられる。しかし，その場合であっても，正面から エネルギー政策の全体像を研究した書籍というには足 りない可能性がある。松井賢一『エネルギー経済・政策 論』では，エネルギー問題の経済的分析を行う中で, “エネルギー政策”に一章を割いて，“エネルギー政策 の分析フレームとして，目的と手段の関係，成果の評 価基準を示し，戦後のわが国のエネルギー政策の変遷 をこの視点から体系的に整理し，政策評価の視点を提 示した”(同書“はじめに”) が, 体系書と呼ぶには至っ ていないと考えられる。この点については，そもそも エネルギーに関する関連諸科学（特に工学）における 研究と一応切り離してエネルギー政策学を独立した学 問として捉えることができるかという観点まで遡って， 別の機会に検討してみたい。 
ギー・環境政策学を専門分野とし，同大学の 2006 年度才 ンラインシラバスによれば，エネルギー政策学ないしエ ネルギー政策研究と題した科目は開講していないものの, 小杉隆信准教授 (専門分野: 環境学・資源エネルギー学) . 佐和隆光教授 (同: 環境経済学・経済政策) とともにリサー チプロジェクト I G・同 III G・同 II GX (以上前期), リサー チプロジェクト II G・同 IV G・同 III GX (以上後期) の科 目を開講している。同科目では, 受講者に各自の具体的 な研究テーマ(領域) を選定させ, 政策分析・評価の研究 を行わせており，エネルギー環境政策論分野のサブテー マ例の一つとしてはエネルギー安全保障問題を示してい る脚注 3 。

\section{3. 隣接学問領域からの示唆}

立命館大学・周教授の専門分野がエネルギー・環境政 策学となっているように，エネルギー政策と環境政策は 密接に関連しており，エネルギー政策学と環境政策学は 隣接学問領域といえよう。したがって，エネルギー政策 学の体系化に当たって, 環境政策学の体系がどのように なっているかを調べることは大いに有意義と考えられる。 環境政策学についても, 前章と同様に, 出版の現状, 教 育の現状の順で見ていきたい。

\section{1 出版の現状}

出版に関連しては，国立国会図書館の蔵書を検索した 限りでは, “環境政策学” と題した体系書は 2 冊確認する ことができた。

第一は, 2000 年 3 月に刊行された石坂匡身編著『環境 政策学』6)である。同書のはしがき部分で, 編著者の石坂 は “近時, これらの個々の問題（引用者注：環境問題を 指す）について論じた書は多く出されるようになってき たが，こうした問題のすべてを包括して有機的，体系的 に俯瞰した書物が極めて少なく，そうした書物が必要だ と考えていた。と述べ, “今回, 志を同じくする数多く の専門家の協力のもとに，環境問題全体を体系的に，問 題の所在と対応を著した書物を世に出すことができた次 第である”と同書成立の事情を紹介している。石坂は元 環境事務次官であり，“数多くの専門家”とは環境庁 (当 時）の課長クラス以下 16 名の政策実務担当官である。

石坂編著の『環境政策学』が提示している環境政策学

脚注 3）このほかに, 東京大学公共政策大学院に“エネルギー・ 地球環境の持続性確保と公共政策”の寄附講座が設置 されているが, 時限的なものであり, また, 所属する鈴 木達治郎客員教授及び諸葛宗男特任教授が担当する科 目は“エネルギー・環境技術の観点から見た産業技術 論” “科学技術と公共政策”及び “環境・技術政策事例 研究” (平成 21 年度は休講) であって, それぞれ“エネ ルギー政策学” の領域を一部含むものの, “エネルギー 政策学” “エネルギー政策論”の科目そのものとは言い がたいと思われる。
の体系は以下の通りである。第 1 部は “環境問題の考え 方”と題して，“序説” “公害としての環境問題” “環境問 題の展開” “古代文明からの示唆” “対応の方向” の 5 章 で構成している。第 2 部が “環境問題対応の政策体系”で あり，“序説” “環境基本法と環境基本計画” “大気污染， 水質污濁, 土壤污染, 地盤沈下への対応” “騒音, 振動, 悪臭への対応” “被害者救済，紛争処理” “費用負担” “自 然環境保全への対応” “廃棄物とリサイクルへの対応” “化 学物質への対応” “地球環境問題への対応” “環境問題解 決のための共通基盤” の 11 章で構成されている。第 1 部 は歴史的アプローチであり，第 2 部はおおよそ政策分野 別アプローチであるといえよう。政策実務担当官の分担 執筆であるから，政策分野別アプローチを採ることが もっとも自然で容易であったものと考えられる。

第二は，2007年11月に刊行された松下和夫著『環境政 策学のすすめ』である7)。松下も環境庁 (省) の行政官出 身であり, 退官後, 京都大学大学院地球環境学堂教授と して環境問題の教育・研究に当たってきたとのことであ る。同書のまえがきで, 松下は “本書は, 筆者の行政の 場における経験や, 国際社会での活動, 大学での講義や 研究の中で考えてきたことを，『環境政策学のすすめ』と してできるだけわかりやすく，体系的にまとめようとし たもの”と紹介しているが，松下の体系化は石坂の体系 化とは少しく異なっている。

全体を 4 部構成とし, 前半は第 I 部“環境政策は何を めざすか”が “なぜ『環境』を学ぶのか”“持続可能な発 展の原則とは” “環境政策と政府の役割”の 3 章構成, 第 II 部 “歴史から学ぶ”が “第二次世界大戦後の環境問題 の変遷一1980 年代後半まで—” “環境問題の国際化と環 境政策の新たな展開一1980年代後半から”の 2 章構成と なっている。石坂編著作の第 1 部に相当するが, 歴史的 アプローチにおいて石坂は第二次世界大戦以前の環境問 題に簡単ながら触れたのに対し, 松下は戦後の環境問題 に限定している点で異なっている。

松下著作の後半は，第吕部“環境政策の原則と手法”が “環境政策の原則と指針” “環境政策の手法とその組合せ (1) 計画的・総合的手法” “環境政策の手法とその組合せ (2)規制的手法, 経済的手法など”の 3 章構成, 第 IV 部“低 炭素社会をめざして”が “地球温暖化問題と低炭素社会 を考える”“人間と地球環境の安全保障” “地球温暖化の 長期的な目標と低炭素社会”の 3 章構成となっている。第 III 部では国内の地域環境問題を扱っているが, 石坂の政 策分野別アプローチに対して，松下は政策手法別アプ ローチを採っており，際立った違いを示している。また， 地球環境問題について, 石坂は一章で扱ったのに対し, 松 下は独立の部を立てて三章を割いており, 出版年次の違 いを踏まえると，21世紀に入ってからの地球環境問題(特 に地球温暖化問題）に対する関心の高まりを反映してい 
ると考えられる。

\section{2 教育の現状}

前述の通り, 各大学のホームページを調べても, エネ ルギー政策学の研究室または専任教員の所在を 3 例しか 見出すことができなかったが，同様の手法で環境政策の 研究室，専任教員を検索してみると，多くの事例が発見 できる。

全く網羅的ではなく，差し当たり見つかった部分のみ を挙げても以下の通りである（大学所在地のおおよそ南 北で排列する)。

まず，国立大学では，東北大学大学院環境科学研究科 に高度環境政策・技術マネジメント人材養成ユニットが 設置されており，筑波大学社会工学系では安田八十五教 授が環境政策学の研究室を開いていた（ただし，安田教 授は現在，関東学院大学経済学部に移っている)。山梨大 学では環境政策学の科目が開講されており，京都大学大 学院地球環境学舎には先述の松下和夫教授が主催する地 球環境政策研究室が開かれている。また，香川大学工学 部で環境政策の科目が開講されており, 愛媛大学農学部 では資源・環境政策学概要のコース, 長崎大学環境科学部 には環境政策コースが，それぞれ開設されている。

公立大学では, 岩手県立大学総合政策学部に環境政策 講座, 静岡県立大学に環境政策研究室, 滋賀県立大学環 境科学部に環境政策・計画学科, 兵庫県立大学環境人間学 部・大学院環境人間学研究科に環境思想・政策コースが, それぞれ置かれている。

私立大学では, 酪農学園大学環境システム学部地域環 境学科で環境政策論を含む”環境政策科目”系列が設定 されており，慶應義塾大学総合政策学部では環境政策分 野を含む環境ガバナンス系列が開設されている。麻布大 学環境保健学部には環境政策学科が置かれており，人間 環境大学では環境政策論, 名古屋産業大学大学院では環 境政策特論が，それぞれ開講されている。鳥取環境大学 では環境政策学科が設置されており，徳島文理大学では 環境政策学，久留米大学経済学部では環境政策論が開講 されている。

このように多くの大学で環境政策学の教育が行われて いることもあり, 日本学術会議環境法学・環境政策学研究 連絡委員会では，1996 年度に法学・政治学・政策学関係 の教育・研究を行っている大学に“『環境法学』『環境政策 学』に関するアンケート調査”を行っており，その時点 で既に 5 学部で環境政策の講義が行われていたことがわ かっている8)。同委員会では 1998 年度，環境法・政策学 の教育・研究に携わる教員を対象としたアンケート調査 も行っており，その結果では 18 大学 18 学部で “環境法” “環境政策”の講義あるいは演習が開講されており，名称 は異なるものの実質的に“環境法” “環境政策”の講義.
演習が 13 大学 13 学部で行われていた (“環境法”を除く “環境政策”のみの数字は明らかにされていない)。

上記のアンケート調査では “環境政策”の講義又は演 習の内容の詳細までは問うていない。このため, 各大学 に打ける教育内容から環境政策学の体系化に資する情報 は得られていない。今後機会があるのであれば，講義又 は演習の内容の詳細まで問うような調査が待たれる。

また，この調査は “環境法”も調査対象としているこ とから明らかなように, 法律系の学部・研究者を主たる対 象としており, 経済系の学部・研究者は含まれていない。 そもそも政策学・政策研究は法学，経済学，政治学・社 会学の学際分野と考えられるが，環境政策については，環 境政策を主たる対象分野とする学会として，環境経済・政 策学会と環境法政策学会が分立している（このほかに環 境科学会, 環境社会学会が先立って設立されている)。

経済系の学部・研究者も対象とした調査が行われれば, 環境政策学の教育・研究に扔ける法学系・政治学系の体 系化と経済学系の体系化の比較対照が可能になるであろ う。その結果, 環境政策学の体系化においても, 法学, 経 済学, 政治学・社会学の研究手法別アプローチが明確化 する可能性がある。

\section{4. エネルギー政策学の体系化の試案}

環境政策学に関する出版及び教育の現状から, 環境政 策学の体系化には以下の 4 つのアプローチがありうるこ とが明らかとなった。

a. 歴史的アプローチ

b. 政策分野別アプローチ

c. 政策手法別アプローチ

d. 研究手法別アプローチ

これらのアプローチはエネルギー政策学の体系化に揖 いても適用可能であろう。これらのアプローチを組み合 わせて, エネルギー政策学体系の試案を教科書の目次の イメージで提示すれば，以下の通りである。

〈エネルギー政策学体系（試案）＞

I．序論：エネルギー政策学の意義

II . 総論

1. エネルギー政策の歴史（〔a. 歴史的アプローチ）

(1) 近世以前のエネルギー政策 (国内各地域内での需 給関係が中心)

(2)近代以降，第二次世界大戦までのエネルギー政策 （国内での需給関係が中心）

(3) 第二次世界大戦後のエネルギー政策 (国際的な需 給関係が中心)

2. エネルギー政策学の研究手法 $(\leftarrow d$. 研究手法別ア プローチ)

(1) 法学的研究手法 
(2) 政治学的・社会学的研究手法

(3) 経済学的研究手法

III. 各論

1. エネルギー政策の目標
(1)エネルギー安全保障
(2)エネルギーの環境調和
(3)エネルギーの経済性

2. エネルギー政策の手法 (〔c.政策手法別アプローチ)

(1)計画的手法（長期計画など）

（2）規制的手法（事業規制，安全規制など）

(3)経済的手法（税，補助金など）

(4) 供与的手法（広報，技術開発など）

3. 分野別のエネルギー政策 $(\leftarrow$ c. 政策分野別アプロー 千)

(1)エネルギー需要政策

(2)エネルギー供給政策

(1)石油・天然ガス政策

(2)石炭政策

(3)原子力政策脚注 4)

(4)新エネルギー政策

(5)電力・ガス事業政策

IV . 結語：エネルギー政策学の今後の課題

\section{5. 今後の取り組みの方向性}

エネルギー政策学の体系化を進めるに際して，差し当 たりは, 大学・大学院で “エネルギー政策学”。“エネル ギー政策論”以外の名称で開講されているエネルギー関 係の科目であって，実質的に“エネルギー政策学” の教 育が行われている可能性があるものを調べる必要があり, 大学・大学院を対象にした悉皆的な調査を行う必要がある であろう。

このような調査は一研究者の手に余るものであり, 環 境政策学について行われたように学術団体が組織的に行 うことが望まれる。エネルギー政策学については, 幸い 日本エネルギー学会が “エネルギー学” 専門部会を設置 してその研究を振興しているので, 同研究会の事業とし
て調査を行うことが可能と思われる。

また，本稿で提案したエネルギー政策学の演繹的な体 系化，いわばトップダウンの手法に対して，エネルギー 政策学の各分野·領域の個別的な体系化を先行的に進め, その集大成としてエネルギー政策学全体の体系化を進め る帰納的, ボトムアップの手法も考えられる。原子力政 策については, 上述の通り概論書の刊行準備が進展して いるが, 同様にエネルギー需要政策学なり石油政策学あ るいは石炭政策学なりについて, 体系的な概論書が刊行 されることははなはだ有意義であろう。国立国会図書館 の蔵書を検索する限り, これら諸学についての概論書的 な著作は未だ公刊されていないと思われる。

エネルギー政策学の隣接領域である環境政策学では, 政策当局者あるいは研究者によって体系的概論書が刊行 されている。その後塵を扯したとはいえ, エネルギー政 策学の概論書が一日も早く上梓されることを期待したい。

\section{謝 辞}

本稿をとりまとめるにあたっては，筆者が所属するエ ネルギー政策研究会の場を通じて, 神田啓治・ 中达良廣 両京都大学名誉教授及び国吉浩氏から多くの示唆, 教示 を得た。また, 宇根崎博信京都大学教授及び蒲生孝治京 都女子大学教授から講義シラバスをご提示いただくとと もに, 東京大学公共政策大学院の鈴木達治郎客員教授及 び諸葛宗男特任教授から担当科目についてご教示いただ いた。記して感謝したい。

\section{文 献: References}

1）宮川公男，政策科学の基礎，（東洋経済新報社）, (1994)

2）足立幸男編著, 政策学的思考とは何か, (勁草書房), (2005)

3）松井賢一, エネルギー経済・政策論, (嵯峨野書院), (2000)

4) 電力中央研究所エネルギー教育研究会, 講座 現代エ
脚注 4） 筆者が 2001 年から 2002 年にかけて在籍した京都大学 大学院エネルギー科学研究科のエネルギー政策学研究 室では現在, これまでの在学者の学位論文の要点をま とめて原子力政策学の概論書を編纂しているところで ある。分野別のエネルギー政策の内容の例となるもの として，その当初の構成案を紹介すれば，以下の通り となる。一研究室での論文集でもあるという書籍の性 格から，原子力政策学の体系として完全なものではな いが，今後，原子力政策学の体系化に当たって参考に なりうるものと考える。

I. 序一原子力政策学の意義

II. 総論

1. 原子力の政策形成

2. 原子力の社会的受容性

3. 原子力とエネルギー安全保障
4. 原子力と地球環境

III. 各論 1 : 原子力産業政策

1. 原子力広報

2. 原子力立地

3. 廃棄物処分

IV. 各論 2 ：原子力安全政策

1. 規制法体系

2. 放射線管理

3. 原子力損害賠償

V. 各論 3 : 核不拡散政策

1. 保障措置

2. 輸出入管理

3. 核防護

VI. 結語一原子力政策学の今後 
ネルギー・環境論 [改定新版], (エネルギーフォーラ 厶), (2006)

5）地球温暖化対策推進本部事務局他監修, 京都議定書目 標達成計画の全容,(小学館クリエイティブ), (2005)

6) 石坂匡身編著, 環境政策学, (中央法規出版), (2000)

7）松下和夫，環境政策学のすすめ，(丸善)，(2007）
8）日本学術会議 環境法学・環境政策学研究連絡委員 会，大学における「環境法学」・「環境政策学」教育の現 状と課題, (2000)<http://www.scj.go.jp/ja/info/ kohyo/17youshi/1722.html > (last visited at Sep. 30, 2008) 